\title{
Mobilization of hematopoietic stem cells from the bone marrow niche to the blood compartment
}

\author{
Jonathan Hoggatt and Louis M Pelus*
}

\begin{abstract}
The vast majority of hematopoietic stem cells (HSCs) reside in specialized niches within the bone marrow during steady state, maintaining lifelong blood cell production. A small number of HSCs normally traffic throughout the body; however, exogenous stimuli can enhance their release from the niche and entry into the peripheral circulation. This process, termed mobilization, has become the primary means to acquire a stem cell graft for hematopoietic transplant at most transplant centers. Currently, the preferred method of HSC mobilization for subsequent transplantation is treatment of the donor with granulocyte colony-stimulating factor. The mobilizing effect of granulocyte colony-stimulating factor is not completely understood, but recent studies suggest that its capacity to mobilize HSCs, at least in part, is a consequence of alterations to the hematopoietic niche. The present article reviews some of the key mechanisms mediating HSC mobilization, highlighting recent advances and controversies in the field.
\end{abstract}

\section{Introduction}

Higher organisms have the remarkable capacity to produce and maintain adequate numbers of blood cells throughout their entire lifespan to meet the normal physiological requirements of blood cell turnover, as well as to respond to needs for increased blood cell demand as a consequence of injury or infection. At the center of lifelong blood cell production is the hematopoietic stem cell (HSC), with the capacity to give rise to all mature circulating blood cell types. Regulation of HSC function is a highly complex process involving not only intrinsic cues within the HSC themselves, but signaling from the surrounding microenvironment in which they reside. It

*Correspondence: Ipelus@iupui.edu

Department of Microbiology \& Immunology, Indiana University School of Medicine, 950 West Walnut Street, R2-302, Indianapolis, IN 46202, USA was first postulated by Schofield that defined local microenvironments created specialized stem cell niches that regulated HSCs [1]. Bone marrow is the primary HSC niche in mammals and is composed of stromal cells and an extracellular matrix of collagens, fibronectin, proteoglycans [2], and endosteal lining osteoblasts [3-6]. HSCs are thought to be tethered to osteoblasts, other stromal cells, and the extracellular matrix in this stem cell niche through a variety of adhesion molecule interactions, many of which are probably redundant systems.

Disruption of one or more of these niche interactions can result in release of HSCs from the niche and their trafficking from the bone marrow to the peripheral circulation, a process termed peripheral blood stem cell mobilization. Mobilization can be achieved through administration of chemotherapy [7-9], hematopoietic growth factors, chemokines and small-molecule chemokine receptor inhibitors or antibodies against HSC niche interactions [10-12].

The process of mobilization has been exploited for collection of hematopoietic stem and progenitor cells (HSPCs) and is widely used for hematopoietic transplantation in both the autologous and allogeneic settings. Mobilized peripheral blood hematopoietic stem cell grafts are associated with more rapid engraftment, reduction in infectious complications and, in patients with advanced malignancies, lower regimen-related mortality [13-15] compared with bone marrow grafts. In many transplantation centers, mobilized HSC grafts are now the preferred hematopoietic stem cell source used for human leukocyte antigen-identical sibling transplants as well as for matched related and unrelated donor transplants [16,17]. Granulocyte colony-stimulating factor (G-CSF), granulocyte-macrophage colony-stimulating factor and - more recently, for patients who fail to mobilize with a G-CSF or granulocyte-macrophage colony-stimulating factor - plerixafor (AMD3100) are the only US Food and Drug Administration-approved agents for mobilizing HSCs. Despite the clinical prevalence of peripheral blood stem and progenitor cell mobilization, the mechanisms orchestrating the release of these cells from the hematopoietic niche are still not completely understood. In the following sections, we 
highlight some of the key mechanistic findings concerning HSPC mobilization, with an emphasis on the effects of mobilizing agents on bone marrow niche interactions.

\section{CXCR4/SDF-1a: the paradigm of mobilization}

The most explored HSC niche interaction is between the CXC4 chemokine receptor (CXCR4) and its ligand, stromal cell-derived factor $1 \alpha$ (SDF- $1 \alpha)$. SDF- $1 \alpha$ is produced by osteoblasts [18], a specialized set of reticular cells found in endosteal and vascular niches [19], endothelial cells and bone itself [20,21], and high levels of SDF- $1 \alpha$ were observed recently in nestin-positive mesenchymal stem cells [22]. HSPCs express CXCR4 and are chemoattracted to and retained within the bone marrow by SDF-1 $\alpha$ [23-25]. Genetic knockout of either CXCR4 [26] or SDF-1 $\alpha$ [27] in mice is embryonically lethal, with a failure of HSPCs to traffic to the bone marrow niche during development. In addition, conditional CXCR4 knockout in mice results in a substantial egress of hematopoietic cells from the bone marrow [28] and impaired ability of CXCR4 knockout HSPCs to be retained within the bone marrow after transplantation [29].

Many agents reported to mobilize HSCs have been shown to disrupt the CXCR4/SDF-1 $\alpha$ axis. Most notably, the CXCR4 antagonist AMD3100 (Plerixafor; Mozobil ${ }^{\mathrm{TM}}$, Genzyme Corporation, Cambridge, MA, USA) mobilizes HSPCs [30-35]; and similarly, the CXCR4 antagonists T140 [36] and T134 [37] are both capable of mobilization. Partially agonizing CXCR4 with SDF- $1 \alpha$ mimetics including (met)-SDF-1 $\beta$ [38], CTCE-0214 [39], and CTCE-0021 [35] also mobilizes HSCs through CXCR4 receptor desensitization and/or downregulation of surface CXCR4 expression. Intriguingly, these agents that directly disrupt the CXCR4/SDF-1 $\alpha$ axis lead to rapid mobilization of HSPCs - that is, hours after treatment in contrast to other mobilization agents like G-CSF, which take several days to maximally mobilize HSPCs.

Despite the abundance of evidence supporting a key role for the CXCR4/SDF- $1 \alpha$ axis in HSPC retention/ trafficking/mobilization, it is still not clear which population of cells within the bone marrow niche is the predominate source of SDF-1 $\alpha$. Some studies have demonstrated that SDF- $1 \alpha$ production by osteoblasts is reduced after G-CSF treatment $[21,40,41]$, and seminal work by Katayama and colleagues suggests that this reduction in osteoblast SDF- $1 \alpha$ is at least partly mediated by the sympathetic nervous system [21]. Notwithstanding the fact that decreased levels of SDF- $1 \alpha$ production by osteoblasts are routinely seen following G-CSF administration, however, other studies have questioned the relative importance of osteoblast-derived SDF-1 $\alpha$ in HSC maintenance and mobilization $[19,22,42]$. A recent study by Christopher and colleagues indicated that reduction in osteoblast production of SDF- $1 \alpha$ is a common mechanism of cytokine-induced HSC mobilization and showed a specific reduction in SDF-1 $\alpha$ production in Col2.3expressing osteoblasts with no reduction in Col2.3negative stromal cells [43]. Mendez-Ferrer and colleagues, however, showed, using a similar approach, a substantial decrease in SDF-1 $\alpha$ in a novel population of nestinexpressing mesenchymal stem cells [22], relative to a similar population of stromal cells described by Christopher and colleagues [43], although a direct comparison with defined osteoblasts was not made. Future studies are clearly required in order to define the specific niche cells responsible for SDF- $1 \alpha$ production and HSC retention, and may identify specific targets for future HSC therapies.

\section{There is more to an osteoblast than SDF-1a}

Osteoblasts are important HSC regulators [3-6], and express numerous signaling molecules in addition to SDF-1 $\alpha$ that regulate HSC function and retention in the bone marrow niche. Osteoblasts express vascular cell adhesion molecule 1 (VCAM-1), and targeting the interaction between very late antigen 4 (VLA-4) and VCAM-1 with either antibodies against VLA-4 [44,45], antibodies against VCAM-1 [46,47], or a small molecule inhibitor of VLA-4 (BIO5192) [48] results in HPSC mobilization. In addition, the Eph-ephrin A3 signaling axis increases adhesion to fibronectin and VCAM-1, and disruption of this signaling axis in vivo with a soluble EphA3-Fc fusion protein mobilizes HSPCs [49].

Osteoblasts also express significant amounts of osteopontin, and HSPCs adhere to osteopontin via $\beta_{1}$ integrins, such as VLA-4 [50]. Osteopontin is a negative regulator of HSC pool size within the bone marrow niche [50,51], and knockout of osteopontin in mice results in endogenous HSPC mobilization and increases the mobilization response to G-CSF [52]. Future therapies that target osteopontin may not only increase the HSC pool size available for hematopoietic mobilization, but may also act to untether the expanded HSCs from the bone marrow niche, resulting in significantly enhanced HSC mobilization.

Mobilizing regimens of G-CSF are associated with suppression of niche osteoblasts [21,41,53], with increased osteoblast apoptosis [41] and osteoblast flattening [21], resulting in significant decreases in endosteal niche expression of many of the above-mentioned retention molecules. This suppression has been reported to be the result of altered sympathetic nervous system signaling to osteoblasts [21]. A recent report by Winkler and colleagues demonstrated that G-CSF treatment results in the reduction of endosteal-lining osteomacs, which results in suppression of osteoblasts [53]. This osteomac population of cells is $\mathrm{F} 4 / 80^{+} \mathrm{Ly}-6 \mathrm{G}^{+} \mathrm{CD} 11 \mathrm{~b}^{+}$and provides a yet to be determined positive supporting role for osteoblasts. 
When osteomacs are depleted using Mafia transgenic mice or by treatment of mice with clodronate-loaded liposomes, significant mobilization of HSPCs was observed. These findings support a mechanistic role for osteoblasts in mediating G-CSF-induced mobilization, independent of the sympathetic nervous system, and highlight that multiple mechanisms may be responsible for the mobilizing effects of G-CSF.

\section{What about osteoclasts?}

Osteoblasts and osteoclasts regulate/coordinate bone formation and bone resorption, respectively, within the bone marrow niche. A report from Kollet and colleagues suggested that osteoclasts can mediate HSPC mobilization [54], and proposed a model where the balance between osteoblasts and osteoclasts is required for homeostatic maintenance of the stem cell niche and HSPC pool size. In their model, increased osteoblasts for example, after parathyroid hormone administration [3] - increase the stem cell pool size and adherence in the niche, whereas increased osteoclasts degrade the niche facilitating release and egress of HSPCs.

A role for osteoclasts in mobilization was shown by treating mice with RANK ligand, which increased osteoclast activity that correlated with a moderate increase in hematopoietic progenitor cell (HPC) mobilization [54]. Similarly, bleeding mice or treating them with lipopolysaccharide, two models of physiological stress, resulted in an increase in the number of bone marrow niche osteoclasts as well as HPC mobilization. Inhibition of osteoclasts, either by treatment with calcitonin or using a genetic knockout model of $\mathrm{PTP}_{\varepsilon}$ in female mice, resulted in a reduced HPC mobilization response to G-CSF compared with controls, further suggesting that osteoclasts were involved in G-CSF-mediated mobilization. The authors proposed that osteoclast-derived proteolytic enzymes, such as cathepsin $K$, degraded important niche interaction components including SDF- $1 \alpha$ and osteopontin, thereby facilitating mobilization [54]. A more recent study by the same laboratory demonstrated reduced osteoclast maturation and activity in CD45 knockout mice, which correlated with reduced mobilization to RANK ligand and G-CSF [55], providing an additional link between osteoclast activity and HSPC mobilization.

In contrast to studies showing that increased osteoclasts enhance HPC mobilization, an earlier report by Takamatsu and colleagues demonstrated that while G-CSF treatment increases osteoclast number and bone resorption in both $\mathrm{BALB} / \mathrm{c}$ mice and humans, the increase in osteoclasts did not occur until 10 to 15 days or 6 to 8 days, respectively, after treatment with G-CSF [56] - a finding that has also been observed by other groups using similar systems [40,57]. Since HSPC mobilization by G-CSF is typically evaluated after 4 to
5 days, the importance of osteoclasts to HSPC mobilization in response to G-CSF treatment remains unclear. Furthermore, treatment of mice with bisphosphonates, which inhibit osteoclast activity and/or number, prior to G-CSF administration does not result in an impaired HSPC mobilization response [53,56]; in fact, in one case, bisphosphonate treatment increased mobilization by G-CSF [53]. These studies suggest that while osteoclasts elicit mechanisms that can induce hematopoietic stem and progenitor mobilization, their role in clinical HSC mobilization with G-CSF is not sufficiently defined and may not be a primary mechanism of mobilization.

The endosteal surface of bone, particularly at the site of resorbing osteoclasts, is a significant source of soluble extracellular calcium within the bone marrow niche. Studies by Adams and colleagues demonstrated that HSCs express calcium-sensing receptors and are chemoattracted to soluble $\mathrm{Ca}^{2+}$ [58]. When the gene for the calcium-sensing receptor was knocked out, mice had reduced HSC content within the bone marrow niche and increased HSCs in peripheral blood. Moreover, calciumsensing receptor-knockout HSCs failed to engraft in hematopoietic transplantation experiments. These results suggest that $\mathrm{Ca}^{2+}$ at the endosteal surface is an important retention signal within the hematopoietic niche and that pharmacologic antagonism of the HSC calcium-sensing receptor may represent a possible strategy for HSPC mobilization.

\section{Oxygen regulation of hematopoietic stem cell mobilization}

The bone marrow hematopoietic niche has been shown to be hypoxic $[59,60]$. HSCs that reside in hypoxic niches have also been shown to have greater hematopoieticrepopulating ability than those that do not [61]. A known physiological response to hypoxia is stabilization of the transcription factor hypoxia inducible factor $1 \alpha$ (HIF-1 $\alpha)$. HIF- $1 \alpha$ has been shown to upregulate erythropoietin production [62], numerous cell proliferation and survival genes [63-65], the angiogenic vascular endothelial growth factor [66], and other genes. It has also been suggested that the hypoxic bone marrow niche maintains HIF-1 $\alpha$ activity, thereby maintaining stem cells [67] - a hypothesis supported by the fact that hypoxic conditions expand human HSCs [68] and HPC populations [69-71] in vitro. In response to G-CSF, both the hypoxic environment and HIF-1 $\alpha$ expand within the bone marrow compartment [72] and increase production of vascular endothelial growth factor $\mathrm{A}$; however, bone marrow vascular density and permeability are not increased [61]. HIF- $1 \alpha$ also increases production of SDF-1 $\alpha$ [73] and CXCR4 receptor expression [74], suggesting that hypoxia may be a physiological regulator of this important signaling axis within the hematopoietic niche. 
HIF- $1 \alpha$ has recently been reported to prevent hematopoietic cell damage caused by overproduction of reactive oxygen species [75], suggesting that the hypoxic niche helps maintain the long lifespan of HSCs. However, some small degree of reactive oxygen species signaling may be necessary for HSC mobilization. A recent report demonstrated that enhanced c-Met activity promotes HSPC mobilization by activating $\mathrm{mTOR}$ and increasing reactive oxygen species production in HSPCs [76], while inhibition of mTOR with rapamycin reduced HSC mobilization $[76,77]$. Genetic knockout of the gene for thioredoxininteracting protein also results in increased HSPC mobilization under stress conditions [78], suggesting a role for oxygen tension and reactive oxygen species in regulation of hematopoietic stem and progenitor mobilization. These findings clearly warrant additional exploration.

\section{Control of the bone marrow niche by the nervous system}

It has been known for some time that there is dynamic interaction between the bone marrow niche and the nervous system. Studies by Katayama and colleagues demonstrated that HSPC mobilization by G-CSF requires peripheral $\beta_{2}$-adrenergic signals [21], showing that GCSF mobilization was reduced in chemically sympathectomized mice treated with 6-hydroxydopamine, in mice treated with the $\beta$-blocker propanolol, or in mice genetically deficient in the gene for dopamine $\beta$ hydroxylase (Dbh), an enzyme that converts dopamine into norepinephrine. They also showed that treatment with the $\beta_{2}$-adrenergic agonist clenbuterol reversed the phenotype of Dbh knockout mice [21]. Intriguingly, G-CSF attenuated osteoblast function via the sympathetic nervous system resulting in osteoblasts having a marked flattened appearance. The effects of nervous system signaling can also be mediated directly on HSCs, as human $\mathrm{CD} 4^{+}$hematopoietic cells express $\beta_{2}$-adrenergic and dopamine receptors that are upregulated after G-CSF treatment [79]. Neurotransmitters serve as direct chemoattractants to HSPCs, and treatment with norepinephrine results in HSC mobilization [79]. Norepinephrine treatment of mice has also been shown to increase CXCR4 receptor expression [80], perhaps suggesting that adrenergic signaling could directly affect CXCR4/SDF- $1 \alpha$ signaling in HSPCs. Additional studies directly assessing effects of neurotransmitter signaling in HSPCs will help to further define the role of the nervous system in hematopoietic regulation.

Not only does the sympathetic nervous system affect HSC mobilization during stress situations, but it also regulates HSC trafficking via a circadian rhythm [81,82]. $\beta_{3}$-Adrenergic stimulations demonstrate regular oscillations controlling norepinephrine release, CXCR4 expression, and SDF-1 $\alpha$ production, leading to rhythmic release of HSPCs from the bone marrow niche. Intriguingly, while optimal mobilization occurs in the morning in mice (Zeitgeber time 5), HSC mobilization circadian control is inverted in humans, with peak mobilization occurring later in the evening [81]. Mobilization by both G-CSF and AMD3100 is affected by circadian control of the CXCR4/SDF- $1 \alpha$ axis. Recently, it was demonstrated that $\beta_{2}$-adrenergic signaling upregulates the vitamin $D$ receptor on osteoblasts; that expression of this receptor is necessary for the G-CSF-induced suppression of osteoblast function; and that vitamin $\mathrm{D}$ receptor knockout mice have reduced HSC mobilization [83]. Intriguingly, vitamin $\mathrm{D}$ receptor is an important regulator of extracellular calcium and HSPC localization [84] and the receptor is also regulated by circadian rhythms [85], possibly suggesting additional interconnected mobilization mechanisms. Further assessment of the role of nervous system signaling and vitamin D receptor signaling on other niche cells, particularly mesenchymal stem cells, should be performed.

\section{Conclusion}

There has been significant progress in understanding the mechanisms of action of G-CSF and other stimuli that increase HSPC trafficking/mobilization. As described in the present review, however, there is currently an abundance of proposed mechanisms that may be responsible for mobilization. This raises the question of whether the proposed mechanisms, be they HSPC intrinsic or manifested through the bone marrow niche, truly represent alternate and independent means to mobilize or enhance egress of HSPCs from bone marrow to the circulation, or whether we have not yet found the unifying mechanism.

Intriguingly, many of the proposed mechanisms of mobilization converge on the CXCR4/SDF-1 $\alpha$ pathway (Figure 1). Alterations of the osteoblast/osteoclast balance result in a reduction of SDF- $1 \alpha$ production and/ or degradation of SDF- $1 \alpha$ by proteases. Signaling from the sympathetic nervous system, stimulated by G-CSF, can alter the osteoblast/osteoclast balance leading to reduced CXCR4/SDF-1 $\alpha$ signaling and HSPC mobilization. Circadian rhythms act to reduce niche SDF- $1 \alpha$ production and HSPC CXCR4 expression in an oscillating manner, suggesting that clinical mobilization should be performed at the trough of SDF-1 $\alpha$ and CXCR4 expression (early night for humans) and perhaps suggesting that clinical transplantation should be performed at the peak of expression (early morning in humans). The hypoxic nature of the hematopoietic bone marrow niche may itself regulate the CXCR4/SDF- $1 \alpha$ signaling axis, perhaps further identifying this axis as a unifying mobilization mechanism. The importance of CXCR4 signaling in HSPC retention and mobilization is certainly 


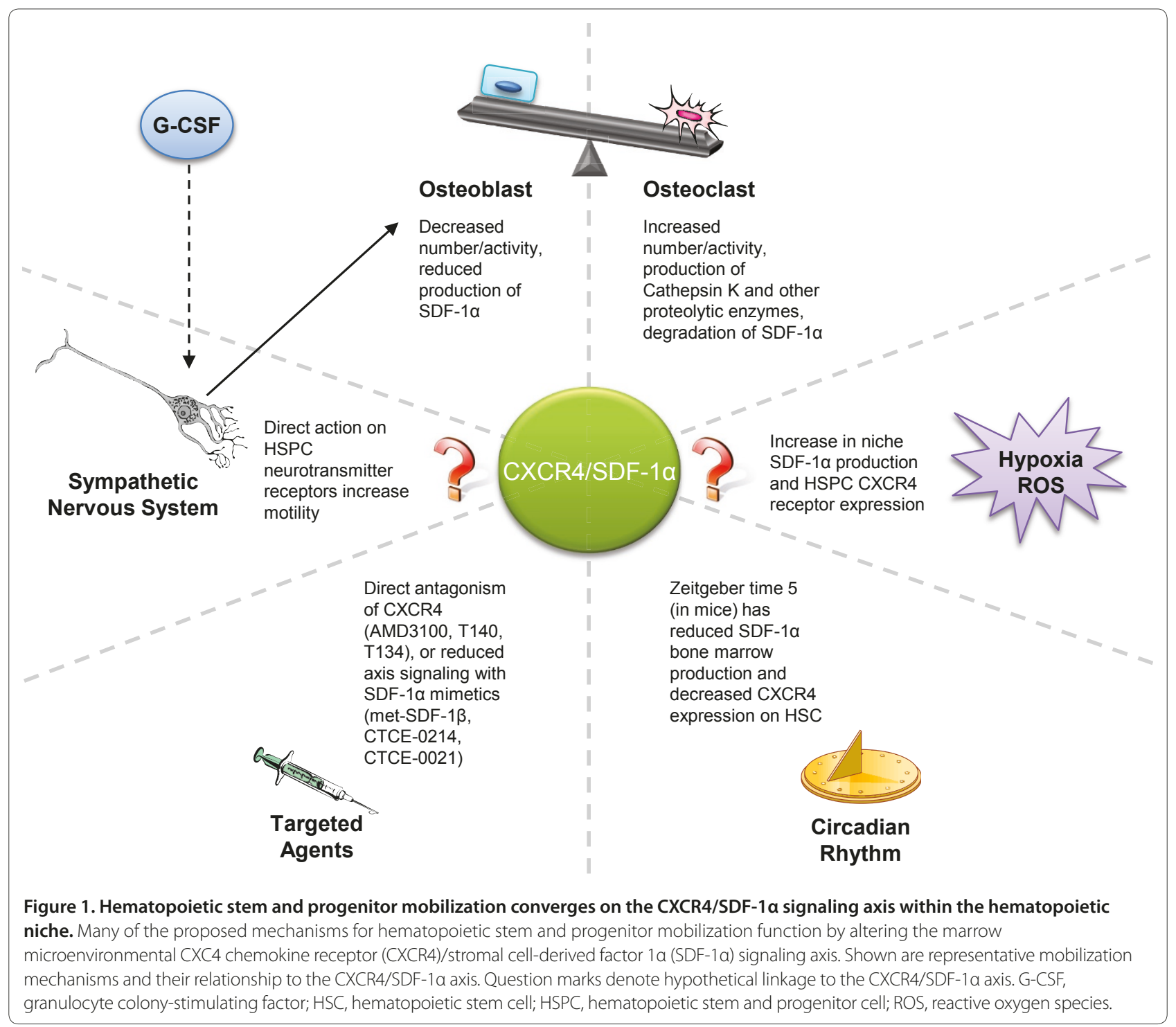

supported by the abundance of agents that directly antagonize, or compete with SDF- $1 \alpha$ and partially agonize, the CXCR4 receptor and result in HSPC mobilization. Even a rapid mobilizing agent such as GRO $\beta$ (CXCR2 agonist) may function by increasing proteolytic cleavage of SDF-1 $\alpha[86,87]$, or altering a homeostatic balance between the CXCR4 and CXCR2 signaling pathways [88].

While perhaps connecting many of the proposed mechanistic pathways for HSPC mobilization, however, the CXCR4/SDF-1 $\alpha$ pathway does not appear to be an exclusive target for HSPC mobilization. Continued investigation of the molecular mechanism(s) for action of

This article is part of a review series on Stem cell niche. Other articles in the series can be found online at http://stemcellres.com/series/ stemcellniche
G-CSF and other HSPC mobilizers is warranted and may define new molecular targets that can be used to enhance the magnitude and/or ease of HSPC collection for hematopoietic transplant.

\section{Abbreviations}

CXCR4, CXC4 chemokine receptor; G-CSF, granulocyte colony-stimulating factor; HIF-1a, hypoxia inducible factor 1a; HPC, hematopoietic progenitor cell; HSC, hematopoietic stem cell; HSPC, hematopoietic stem and progenitor cell; mTOR, mammalian target of rapamycin; RANK, receptor activator NF-KB; SDF1a, stromal cell-derived factor 1a; VCAM-1, vascular cell adhesion molecule 1; VLA-4, late antigen 4.

Competing interests

The authors declare that they have no competing interests.

\section{Acknowledgements}

The present work was supported by NIH grants HL069669 and HL096305 (to LMP). JH is supported by training grant HL007910.

Published: 14 March 2011 


\section{References}

1. Schofield R: The relationship between the spleen colony-forming cell and the haemopoietic stem cell. Blood Cells 1978, 4:7-25.

2. Yoder MC, Williams DA: Matrix molecule interactions with hematopoietic stem cells. Exp Hematol 1995, 23:961-967.

3. Calvi LM, Adams GB, Weibrecht KW, Weber JM, Olson DP, Knight MC, Martin RP, Schipani E, Divieti P, Bringhurst FR, Milner LA, Kronenberg HM, Scadden DT: Osteoblastic cells regulate the haematopoietic stem cell niche. Nature 2003, 425:841-846.

4. Zhang J, Niu C, Ye L, Huang H, He X, Tong WG, Ross J, Haug J, Johnson T, Feng JQ, Harris S, Wiedemann LM, Mishina Y, Li L: Identification of the haematopoietic stem cell niche and control of the niche size. Nature 2003 425:836-841.

5. Visnjic D, Kalajzic Z, Rowe DW, Katavic V, Lorenzo J, Aguila HL: Hematopoiesis is severely altered in mice with an induced osteoblast deficiency. Blood 2004, 103:3258-3264.

6. Arai F, Hirao A, Ohmura M, Sato H, Matsuoka S, Takubo K, Ito K, Koh GY, Suda T: Tie2/angiopoietin-1 signaling regulates hematopoietic stem cell quiescence in the bone marrow niche. Cell 2004, 118:149-161.

7. Kessinger A, Armitage JO: The evolving role of autologous peripheral stem cell transplantation following high-dose therapy for malignancies. Blood 1991, 77:211-213.

8. Kurnick JE, Robison WA: Colony growth of human peripheral white blood cells in vitro. Blood 1971, 37:136-141.

9. McCredie KB, Hersh EM, Freireich EJ: Cells capable of colony formation in the peripheral blood of man. Science 1971, 171:293-294.

10. Fruehauf $S$, Seggewiss $R$ : It's moving day: factors affecting peripheral blood stem cell mobilization and strategies for improvement [corrected]. $\mathrm{Br}$ ] Haemato/ 2003, 122:360-375

11. Papayannopoulou T: Current mechanistic scenarios in hematopoietic stem/ progenitor cell mobilization. Blood 2004, 103:1580-1585.

12. To LB, Haylock DN, Simmons PJ, Juttner CA: The biology and clinical uses of blood stem cells. Blood 1997, 89:2233-2258.

13. Bensinger WI, Martin PJ, Storer B, Clift R, Forman SJ, Negrin R, Kashyap A, FLowers ME, Lilleby K, Chauncey TR, Storb R, Appelbaum FR: Transplantation of bone marrow as compared with peripheral-blood cells from HLAidntical relatives in patients with hematologic cancers. N Eng/ J Med 2001, 344:175-181.

14. Champlin RE, Schmitz N, Horowitz MM, Chapuis B, Chopra R, Cornelissen JJ, Gale RP, Goldman JM, Loberiza FR, Jr, Hertenstein B, Klein JP, Montserrat E, Zhang MJ, Ringden O, Tomany SC, Rowlings PA, Van Hoef ME, Gratwohl A Blood stem cells compared with bone marrow as a source of hematopoietic cells for allogeneic transplantation. IBMTR Histocompatibility and Stem Cell Sources Working Committee and the European Group for Blood and Marrow Transplantation (EBMT). Blood 2000, 95:3702-3709

15. Korbling $M$, Anderlini P: Peripheral blood stem cell versus bone marrow allotransplantation: does the source of hematopoietic stem cells matter? Blood 2001, 98:2900-2908.

16. Cashen AF, Lazarus HM, Devine SM: Mobilizing stem cells from normal donors: is it possible to improve upon G-CSF? Bone Marrow Transplant 2007, 39:577-588

17. Gratwohl A, Baldomero H, Horisberger B, Schmid C, Passweg J, UrbanoIspizua A: Current trends in hematopoietic stem cell transplantation in Europe. Blood 2002, 100:2374-2386.

18. Ponomaryov T, Peled A, Petit I, Taichman RS, Habler L, Sandbank J, ArenzanaSeisdedos F, Magerus A, Caruz A, Fujii N, Nagler A, Lahav M, Szyper-Kravitz M Zipori D, Lapidot T: Induction of the chemokine stromal-derived factor- 1 following DNA damage improves human stem cell function. J Clin Invest 2000, 106:1331-1339.

19. Sugiyama T, Kohara H, Noda M, Nagasawa T: Maintenance of the hematopoietic stem cell pool by CXCL12-CXCR4 chemokine signaling in bone marrow stromal cell niches. Immunity 2006, 25:977-988.

20. Sipkins DA, Wei X, Wu JW, Runnels JM, Cote D, Means TK, Luster AD, Scadden DT, Lin CP: In vivo imaging of specialized bone marrow endothelial microdomains for tumour engraftment. Nature 2005, 435:969-973.

21. Katayama Y, Battista M, Kao WM, Hidalgo A, Peired AJ, Thomas SA, Frenette PS: Signals from the sympathetic nervous system regulate hematopoietic stem cell egress from bone marrow. Cell 2006, 124:407-421.

22. Mendez-Ferrer S, Michurina TV, Ferraro F, Mazloom AR, Macarthur BD, Lira SA, Scadden DT, Ma'ayan A, Enikolopov GN, Frenette PS: Mesenchymal and haematopoietic stem cells form a unique bone marrow niche. Nature 2010, 466:829-834.

23. Aiuti A, Webb IJ, Bleul C, Springer T, Gutierrez-Ramos JC: The chemokine SDF-1 is a chemoattractant for human $\mathrm{CD}^{4} 4^{+}$hematopoietic progenitor cells and provides a new mechanism to explain the mobilization of CD34 $4^{+}$ progenitors to peripheral blood. J Exp Med 1997, 185:111-120.

24. Jo DY, Rafii S, Hamada T, Moore MA: Chemotaxis of primitive hematopoietic cells in response to stromal cell-derived factor-1.J Clin Invest 2000, 105:101-111

25. Kim CH, Broxmeyer HE: In vitro behavior of hematopoietic progenitor cells under the influence of chemoattractants: stromal cell-derived factor-1, steel factor, and the bone marrow environment. Blood 1998, 91:100-110

26. Zou YR, Kottmann AH, Kuroda M, Taniuchi I, Littman DR: Function of the chemokine receptor CXCR4 in haematopoiesis and in cerebellar development. Nature 1998, 393:595-599.

27. Nagasawa T, Hirota S, Tachibaba K, Takakura N, Nishikawa S, Kitamura Y, Yoshida N, Kikutani H, Kishimoto T: Defects of B-cell lymphopoiesis and bone-marrow myelopoiesis in mice lacking the CXC chemokine PBSF/ SDF-1. Nature 1996, 382:635-638.

28. Nie Y, Han YC, Zou YR: CXCR4 is required for the quiescence of primitive hematopoietic cells. J Exp Med 2008, 205:777-783.

29. Foudi A, Jarrier P, Zhang Y, Wittner M, Geay JF, Lecluse Y, Nagasawa T, Vainchenker W, Louache F: Reduced retention of radioprotective hematopoietic cells within the bone marrow microenvironment in CXCR4-/- chimeric mice. Blood 2006, 107:2243-2251.

30. Broxmeyer HE, Orschell CM, Clapp DW, Hangoc G, Cooper S, Plett PA, Liles WC, Li X, Graham-Evans B, Campbell TB, Calandra G, Bridger G, Dale DC, Srour EF: Rapid mobilization of murine and human hematopoietic stem and progenitor cells with AMD3100, a CXCR4 antagonist. J Exp Med 2005, 201:1307-1318.

31. Broxmeyer HE, Hangoc G, Cooper S, Campbell T, Ito S, Mantel C: AMD3100 and CD26 modulate mobilization, engraftment, and survival of hematopoietic stem and progenitor cells mediated by the SDF-1/CXCL12CXCR4 axis. Ann N Y Acad Sci 2007, 1106:1-19.

32. Devine SM, Vij R, Rettig M, Todt L, McGlauchlen K, Fisher N, Devine H, Link DC, Calandra G, Bridger G, Westervelt P, DiPersio JF: Rapid mobilization of functional donor hematopoietic cells without G-CSF using AMD3100, an antagonist of the CXCR4/SDF-1 interaction. Blood 2008, 112:990-998.

33. Liles WC, Broxmeyer HE, Rodger E, Wood B, Hubel K, Cooper S, Hangoc G, Bridger GJ, Henson GW, Calandra G, Dale DC: Mobilization of hematopoietic progenitor cells in healthy volunteers by AMD3100, a CXCR4 antagonist. Blood 2003, 102:2728-2730

34. Liles WC, Rodger E, Broxmeyer HE, Dehner C, Badel K, Calandra G, Christensen J, Wood B, Price TH, Dale DC: Augmented mobilization and collection of $\mathrm{CD}_{4} 4^{+}$hematopoietic cells from normal human volunteers stimulated with granulocyte-colony-stimulating factor by single-dose administration of AMD3100, a CXCR4 antagonist. Transfusion 2005, 45:295-300,

35. Pelus LM, Bian H, Fukuda S, Wong D, Merzouk A, Salari H: The CXCR4 agonist peptide, CTCE-0021, rapidly mobilizes polymorphonuclear neutrophils and hematopoietic progenitor cells into peripheral blood and synergizes with granulocyte colony-stimulating factor. Exp Hematol 2005, 33:295-307.

36. Abraham M, Biyder K, Begin M, Wald H, Weiss ID, Galun E, Nagler A, Peled A: Enhanced unique pattern of hematopoietic cell mobilization induced by the CXCR4 antagonist 4F-benzoyl-TN14003. Stem Cells 2007, 25:2158-2166.

37. Iyer CV, Evans RJ, Lou Q, Lin D, Wang J, Kohn W, Yan LZ, Pulley S, Peng SB: Rapid and recurrent neutrophil mobilization regulated by T134, a CXCR4 peptide antagonist. Exp Hematol 2008, 36:1098-1109.

38. Shen H, Cheng T, Olszak I, Garcia-Zepeda E, Lu Z, Herrmann S, Fallon R, Luster $A D$, Scadden DT: CXCR-4 desensitization is associated with tissue localization of hemopoietic progenitor cells. J Immunol 2001, 166:5027-5033.

39. Zhong R, Law P, Wong D, Merzouk A, Salari H, Ball ED: Small peptide analogs to stromal derived factor-1 enhance chemotactic migration of human and mouse hematopoietic cells. Exp Hematol 2004, 32:470-475.

40. Christopher MJ, Link DC: Granulocyte colony-stimulating factor induces osteoblast apoptosis and inhibits osteoblast differentiation. J Bone Miner Res 2008, 23:1765-1774.

41. Semerad CL, Christopher MJ, Liu F, Short B, Simmons PJ, Winkler I, Levesque JP, Chappel J, Ross FP, Link DC: G-CSF potently inhibits osteoblast activity and CXCL12 mRNA expression in the bone marrow. Blood 2005, 106:3020-3027. 
42. Tokoyoda K, Egawa T, Sugiyama T, Choi BI, Nagasawa T: Cellular niches controlling B lymphocyte behavior within bone marrow during development. Immunity 2004, 20:707-718

43. Christopher MJ, Liu F, Hilton MJ, Long F, Link DC: Suppression of CXCL12 production by bone marrow osteoblasts is a common and critical pathway for cytokine-induced mobilization. Blood 2009, 114:1331-1339.

44. Craddock CF, Nakamoto B, Andrews RG, Priestley GV, Papayannopoulou T: Antibodies to VLA4 integrin mobilize long-term repopulating cells and augment cytokine-induced mobilization in primates and mice. Blood 1997, 90:4779-4788

45. Papayannopoulou T, Priestley GV, Nakamoto B, Zafiropoulos V, Scott LM: Molecular pathways in bone marrow homing: dominant role of $\alpha(4) \beta(1)$ over $\beta$ (2)-integrins and selectins. Blood 2001, 98:2403-2411.

46. Kikuta T, Shimazaki C, Ashihara E, Sudo Y, Hirai H, Sumikuma T, Yamagata N, Inaba T, Fujita N, Kina T, Nakagawa M: Mobilization of hematopoietic primitive and committed progenitor cells into blood in mice by antivascular adhesion molecule-1 antibody alone or in combination with granulocyte colony-stimulating factor. Exp Hematol 2000, 28:311-317.

47. Papayannopoulou T, Priestley GV, Nakamoto B: Anti-VLA4/VCAM-1-induced mobilization requires cooperative signaling through the kit/mkit ligand pathway. Blood 1998, 91:2231-2239.

48. Ramirez P, Rettig MP, Uy GL, Deych E, Holt MS, Ritchey JK, DiPersio JF: BIO5192, a small molecule inhibitor of VLA-4, mobilizes hematopoietic stem and progenitor cells. Blood 2009, 114:1340-1343.

49. Ting M, Day B, Spanevello M, Boyd A: Activation of ephrin A proteins influences hematopoietic stem cell adhesion and trafficking patterns. Exp Hemato/ 2010, 38:1087-1098.

50. Nilsson SK, Johnston HM, Whitty GA, Williams B, Webb RJ, Denhardt DT, Bertoncello I, Bendall LJ, Simmons PJ, Haylock DN: Osteopontin, a key component of the hematopoietic stem cell niche and regulator of primitive hematopoietic progenitor cells. Blood 2005, 106:1232-1239.

51. Stier S, Ko Y, Forkert R, Lutz C, Neuhaus T, Grunewald E, Cheng T, Dombkowski D, Calvi LM, Rittling SR, Scadden DT: Osteopontin is a hematopoietic stem cell niche component that negatively regulates stem cell pool size. J Exp Med 2005, 201:1781-1791.

52. Grassinger J, Haylock DN, Storan MJ, Haines GO, Williams B, Whitty GA, Vinson AR, Be CL, Li S, Sorensen ES, Tam PP, Denhardt DT, Sheppard D, Choong PF, Nilsson SK: Thrombin-cleaved osteopontin regulates hemopoietic stem and progenitor cell functions through interactions with $\alpha 9 \beta 1$ and $\alpha 4 \beta 1$ integrins. Blood 2009, 114:49-59.

53. Winkler IG, Sims NA, Pettit AR, Barbier V, Nowlan B, Helwani F, Poulton IJ, van RN, Alexander KA, Raggatt $L$, Levesque JP: Bone marrow macrophages maintain hematopoietic stem cell (HSC) niches and their depletion mobilizes HSCs. Blood 2010, 116:4815-4828.

54. Kollet O, Dar A, Shivtiel S, Kalinkovich A, Lapid K, Sztainberg Y, Tesio M, Samstein RM, Goichberg P, Spiegel A, Elson A, Lapidot T: Osteoclasts degrade endosteal components and promote mobilization of hematopoietic progenitor cells. Nat Med 2006, 12:657-664.

55. Shivtiel S, Kollet O, Lapid K, Schajnovitz A, Goichberg P, Kalinkovich A, Shezen E, Tesio M, Netzer N, Petit I, Sharir A, Lapidot T: CD45 regulates retention, motility, and numbers of hematopoietic progenitors, and affects osteoclast remodeling of metaphyseal trabecules. J Exp Med 2008, 205:2381-2395.

56. Takamatsu Y, Simmons PJ, Moore RJ, Morris HA, To LB, Levesque JP: Osteoclast-mediated bone resorption is stimulated during short-term administration of granulocyte colony-stimulating factor but is not responsible for hematopoietic progenitor cell mobilization. Blood 1998, 92:3465-3473

57. Hirbe AC, Uluckan O, Morgan EA, Eagleton MC, Prior JL, Piwnica-Worms D, Trinkaus K, Apicelli A, Weilbaecher K: Granulocyte colony-stimulating factor enhances bone tumor growth in mice in an osteoclast-dependent manner. Blood 2007, 109:3424-3431.

58. Adams GB, Chabner KT, Alley IR, Olson DP, Szczepiorkowski ZM, Poznansky MC, Kos CH, Pollak MR, Brown EM, Scadden DT: Stem cell engraftment at the endosteal niche is specified by the calcium-sensing receptor. Nature 2006, 439:599-603.

59. Parmar K, Mauch P, Vergilio JA, Sackstein R, Down JD: Distribution of hematopoietic stem cells in the bone marrow according to regional hypoxia. Proc Natl Acad Sci U S A 2007, 104:5431-5436.

60. Kubota Y, Takubo K, Suda T: Bone marrow long label-retaining cells reside in the sinusoidal hypoxic niche. Biochem Biophys Res Commun 2008,
366:335-339

61. Winkler IG, Barbier V, Wadley R, Zannettino AC, Williams S, Levesque JP: Positioning of bone marrow hematopoietic and stromal cells relative to blood flow in vivo: serially reconstituting hematopoietic stem cells reside in distinct nonperfused niches. Blood 2010, 116:375-385.

62. Semenza GL, Nejfelt MK, Chi SM, Antonarakis SE: Hypoxia-inducible nuclear factors bind to an enhancer element located 3 ' to the human erythropoietin gene. Proc Natl Acad Sci U S A 1991, 88:5680-5684

63. Feldser D, Agani F, lyer NV, Pak B, Ferreira G, Semenza GL: Reciprocal positive regulation of hypoxia-inducible factor 1alpha and insulin-like growth factor 2. Cancer Res 1999, 59:3915-3918.

64. Cormier-Regard S, Nguyen SV, Claycomb WC: Adrenomedullin gene expression is developmentally regulated and induced by hypoxia in rat ventricular cardiac myocytes. J Biol Chem 1998, 273:17787-17792.

65. Krishnamachary B, Berg-Dixon S, Kelly B, Agani F, Feldser D, Ferreira G, Iyer N, LaRusch J, Pak B, Taghavi P, Semenza GL: Regulation of colon carcinoma cell invasion by hypoxia-inducible factor 1 . Cancer Res 2003, 63:1138-1143.

66. Levy AP, Levy NS, Wegner S, Goldberg MA: Transcriptional regulation of the rat vascular endothelial growth factor gene by hypoxia. J Biol Chem 1995 , 270:13333-13340.

67. Lin Q, Lee YJ, Yun Z: Differentiation arrest by hypoxia. J Biol Chem 2006, 281:30678-30683.

68. Danet GH, Pan Y, Luongo JL, Bonnet DA, Simon MC: Expansion of human SCID-repopulating cells under hypoxic conditions. J Clin Invest 2003, 112:126-135.

69. Smith S, Broxmeyer HE: The influence of oxygen tension on the long-term growth in vitro of haematopoietic progenitor cells from human cord blood. Br J Haematol 1986, 63:29-34

70. Broxmeyer HE, Cooper S, Gabig T: The effects of oxidizing species derived from molecular oxygen on the proliferation in vitro of human granulocyte-macrophage progenitor cells. Ann N Y Acad Sci 1989, 554:177-184.

71. Broxmeyer HE, Cooper S, Lu L, Miller ME, Langefeld CD, Ralph P: Enhanced stimulation of human bone marrow macrophage colony formation in vitro by recombinant human macrophage colony-stimulating factor in agarose medium and at low oxygen tension. Blood 1990, 76:323-329.

72. Levesque JP, Winkler IG, Hendy J, Williams B, Helwani F, Barbier V, Nowlan B, Nilsson SK: Hematopoietic progenitor cell mobilization results in hypoxia with increased hypoxia-inducible transcription factor-1 alpha and vascular endothelial growth factor A in bone marrow. Stem Cells 2007, 25:1954-1965.

73. Ceradini DJ, Kulkarni AR, Callaghan MJ, Tepper OM, Bastidas N, Kleinman ME, Capla JM, Galiano RD, Levine JP, Gurtner GC: Progenitor cell trafficking is regulated by hypoxic gradients through HIF-1 induction of SDF-1. Nat Med 2004, 10:858-864.

74. Staller P, Sulitkova J, Lisztwan J, Moch H, Oakeley EJ, Krek W: Chemokine receptor CXCR4 downregulated by von Hippel-Lindau tumour suppressor pVHL. Nature 2003, 425:307-311.

75. Kirito K, Hu Y, Komatsu N: HIF-1 prevents the overproduction of mitochondrial ROS after cytokine stimulation through induction of PDK-1. Cell Cycle 2009, 8:2844-2849

76. Tesio M, Golan K, Corso S, Giordano S, Schajnovitz A, Vagima Y, Shivtiel S, Kalinkovich A, Caione L, Gammaitoni L, Laurenti E, Buss EC, Shezen E, Itkin T, Kollet O, Petit I, Trumpp A, Christensen J, Aglietta M, Piacibello W, Lapidot T: Enhanced c-Met activity promotes G-CSF induced mobilization of hematopoietic progenitor cells via ROS signaling. Blood 2011, 117:419-428.

77. Vagima Y, Avigdor A, Goichberg P, Shivtiel S, Tesio M, Kalinkovich A, Golan K, Dar A, Kollet O, Petit I, Perl O, Rosenthal E, Resnick I, Hardan I, Gellman YN, Naor D, Nagler A, Lapidot T: MT1-MMP and RECK are involved in human CD34+ progenitor cell retention, egress, and mobilization. $J$ Clin Invest 2009, 119:492-503.

78. Jeong M, Piao ZH, Kim MS, Lee SH, Yun S, Sun HN, Yoon SR, Chung JW, Kim TD, Jeon JH, Lee J, Kim HN, Choi JY, Choi I: Thioredoxin-interacting protein regulates hematopoietic stem cell quiescence and mobilization under stress conditions. J Immuno/ 2009, 183:2495-2505.

79. Spiegel A, Shivtiel S, Kalinkovich A, Ludin A, Netzer N, Goichberg P, Azaria Y, Resnick I, Hardan I, Ben-Hur H, Nagler A, Rubinstein M, Lapidot T: Catecholaminergic neurotransmitters regulate migration and repopulation of immature human $\mathrm{CD}_{3} 4^{+}$cells through Wnt signaling. Nat Immunol 2007, 8:1123-1131.

80. Gruber-Olipitz M, Stevenson R, Olipitz W, Wagner E, Gesslbauer B, Kungl A, Schauenstein K: Transcriptional pattern analysis of adrenergic 
immunoregulation in mice. Twelve hours norepinephrine treatment alters the expression of a set of genes involved in monocyte activation and leukocyte trafficking. J Neuroimmunol 2004, 155:136-142.

81. Lucas D, Battista M, Shi PA, Isola L, Frenette PS: Mobilized hematopoietic stem cell yield depends on species-specific circadian timing. Cell Stem Cell 2008, 3:364-366.

82. Mendez-Ferrer S, Lucas D, Battista M, Frenette PS: Haematopoietic stem cell release is regulated by circadian oscillations. Nature 2008, 452:442-447.

83. Kawamori Y, Katayama Y, Asada N, Minagawa K, Sato M, Okamura A, Shimoyama M, Nakagawa K, Okano T, Tanimoto M, Kato S, Matsui T: Role for vitamin D receptor in the neuronal control of the hematopoietic stem cell niche. Blood 2010, 116:5528-5535.

84. Jeanson NT, Scadden DT: Vitamin D receptor deletion leads to increased hematopoietic stem and progenitor cells residing in the spleen. Blood 2010, 116:4126-4129.

85. Cho Y, Noshiro M, Choi M, Morita K, Kawamoto T, Fujimoto K, Kato Y, Makishima M: The basic helix-loop-helix proteins differentiated embryo chondrocyte (DEC) 1 and DEC2 function as corepressors of retinoid $X$ receptors. Mol Pharmacol 2009, 76:1360-1369.
86. Pelus LM, Bian H, King AG, Fukuda S: Neutrophil-derived MMP-9 mediates synergistic mobilization of hematopoietic stem and progenitor cells by the combination of G-CSF and the chemokines GRO $\beta / C X C L 2$ and GRO $\beta T$ / CXCL284. Blood 2004, 103:110-119.

87. Pelus LM, Fukuda S: Peripheral blood stem cell mobilization: the CXCR2 ligand GRO $\beta$ rapidly mobilizes hematopoietic stem cells with enhanced engraftment properties. Exp Hemato/ 2006, 34:1010-1020.

88. Eash KJ, Greenbaum AM, Gopalan PK, Link DC: CXCR2 and CXCR4 antagonistically regulate neutrophil trafficking from murine bone marrow. J Clin Invest 2010, 120:2423-2431.

\section{doi:10.1186/scrt54}

Cite this article as: Hoggatt J, Pelus LM: Mobilization of hematopoietic stem cells from the bone marrow niche to the blood compartment. Stem Cell Research \& Therapy 2011, 2:13. 